I Campinas State University (UNICAMP), Campinas, SP, Brazil

mpleite48@gmail.com

II São Paulo Faculty of Technology (FATEC), São Paulo, SP, Brazil

duaibs@gmail.com

Marcia de Paula Leite'

Raquel Duaibs"

\title{
COOPERATIVES AND PRODUCTIVE INTERNATIONALIZATION: A NEW CHALLENGE
}

\section{INTRODUCTION}

First emerging in nineteenth-century England while capitalism was still in its early phase, the cooperativist ideal has remained a source of debate to the present, dividing scholars, trade unionists and the leaders of social movements, like the Solidary Economy movement in Brazil. Evolving as a way of opposing the hardships faced by workers during the period of history in question, from its outset this ideal called for solidarity between workers, collective ownership of the means of production and, with the latter, an end to the exploitation of labour by capital. In this way, it quickly presented itself as a form of organizing production and labour that provided an alternative to capitalism and, as such, became debated by the workers' movement, unions and left-wing groups.

Among the various problems confronted by the cooperativist ventures, the most controversial involves the economic dispute with capitalist companies: generally speaking, when they remain faithful to the principles of solidarity, they are unable to survive the intense capitalist competition; when they become competitive, though, this is because they have already moved away from these ideals and thus from cooperativism itself, although they may retain some of its characteristics.

Given the series of challenges faced, diverse authors assert that cooperatives are fated to degeneration. Such was the case of Beatrice Potter, the 
maiden name of Beatrice Webb, and Sidney Webb, who believed that there was an inevitable tendency for cooperatives to stray from their social objectives due to the fierce pressures of the market economy, which force them to diverge from their principles of solidarity and equality, contrary to the objectives of accumulation and profitmaking.

Along the same lines, Baldacchino argues that cooperatives frequently encounter serious economic difficulties and, when their workers manage to avoid financial ruin, they can become "victims of their own economic success," since the expansion leads to ever higher levels of bureaucratization and, consequently, to the adoption of measures to introduce representative democracy in place of participative democracy.

Pursuing a Marxist analysis, Luxemburg (1999) explores the problematics of cooperativism via her critique of the theory of Eduard Bernstein, who for his part called for the transition to socialism through the constitution of cooperative enterprises. Bernstein describes cooperatives, especially those related to production, as "hybrid institutions" within capitalism that constitute a "socialized production in miniature" at the same time as they maintain capitalist exchange. For Luxemburg too, the market logic forces the cooperative venture to engage in intense exploitation of the workforce as a means to survive competition, a phenomenon that she identifies as a decisive influence of capitalist interests over the cooperative's production process.

Doucouliagos, for his part, seeks to understand the reasons why worker-controlled companies are frequently outperformed by their capitalist peers. The author argues that the collective enterprises are placed at a disadvantage in capitalist economies and undermined by the ideological bias propagated against them. He also points to other obstacles, such as the social and cultural context hostile to the principles of cooperation; the educational training of workers, inadequate for promoting the ideals of solidarity; the risk aversion that they commonly manifest due to a lack of entrepreneurial experience; discrimination from financial institutions, which frequently refuse loans to cooperative ventures; and the forces operating within the capitalist economy that eventually cause the cooperative to degenerate, such as extreme market competition and the constant need to reduce costs.

Analysing the various theses on degeneration, Cornforth (2007) argues that the Webbs' claims concerning the inevitable failure of producer cooperatives are overblown. In his 1995 study, the author points out that although both internal and external factors can influence the experiences of cooperatives, there is no absolutely determinant behaviour applicable to all such ventures, such that they may respond to these experiences differently and, therefore, are not inevitably doomed to failure, even though this may be the fate of many.

These analyses in mind, we believe that cooperativist ideals today face another obstacle leading to degeneration: the globalization of the economy 
and internationalization of companies, including the cooperatives themselves, when their success ends up driving expansion.

This is the question that we sought to investigate through a qualitative study developed in Italy in 20I4, which looked to discuss the scale and impacts of the phenomenon of the productive internationalization of Italian cooperatives in Bologna, Imola, Rome and Pesaro. The field research, which included the application de 17 semi-structured questionnaires, encompassed unions, cooperative support institutions and a cooperative that manufactures machinery (referred to hereafter as Cooperative $\mathrm{X}$ ), whose main line of business is the production of ceramics and which has become a benchmark for cooperativism in the Emilia-Romagna region. As part of the study, we undertook extensive bibliographic research in the local libraries, the results of which were complemented by documentary research and semi-structured interviews with wage workers, cooperative workers, trade unionists and staff from cooperative support institutions. The analysis that follows focuses, in sequence, on the first cooperative experiences in Italy; productive internationalization and its impacts on workers; and the experience of internationalization of Cooperative $\mathrm{X}$.

\section{THE COOPERATIVE EXPERIENCE IN ITALY}

Italian cooperativism provides a model that has become a global benchmark, especially the kind developed in the Emilia-Romagna region in the country's northeast. Indeed, an extensive bibliography already exists on the small companies and, in particular, the cooperatives based in the region, identified as responsible not only for its high levels of economic development, but also for the high quality of life enjoyed by its workers. The region is perceived to be economically powerful and socially balanced, and the role of the cooperatives in the evolution of this scenario has been highlighted by the specialized bibliography. Although this view has been questioned by studies demonstrating the tendency of these small companies to transform into large economic agglomerates, expanding on the basis of cheap labour exploited in other parts of the world, and although the region has also been affected by the global economic crisis over recent years, the image of the cooperatives as the basis of a more egalitarian economy in the Emilia-Romagna region has persisted.

Italy possesses a long tradition of cooperativism, its first experience registered in 1806 with the setting up of a cooperative manufacturing milkbased products in the town of Osoppo, located in the north of the country (Barberini, 2009). Following this experience, the Italian cooperative movement began to flourish and, in I854, the Turin Workers' General Association inaugurated the first consumer cooperative in the form of a pension committee. In 1856 , in the small community of Altare in Savona, the first producer cooperative of local glassworkers was founded. As in England, the first cooperatives 
were linked to the mutual aid societies, and, in a few years, the specialized urban workers united to form arts and crafts corporations. ${ }^{\mathrm{I}}$ Over the following decades dozens of mutual aid societies proliferated in diverse regions of the kingdom. ${ }^{2}$

The Italian cooperative movement, especially its communist and socialist strands, faced two world wars, fascism and neoliberalism together with their respective economic crises and, over the course of history, proved to be the most viable means of saving and protecting workers from unemployment and hunger. As the years passed, it became stronger and institutionalized, and successfully campaigned for diverse federal and regional laws - including the Legge Basevi ${ }^{3}$ and the Legge Marcora ${ }^{4}$ - which fostered its development within the country.

The cooperative is a form of enterprise with a recognizably singular role within the capitalist system. The characteristic element distinguishing it from other companies is the proposal of collective ownership by the workers, who, in theory, manage the venture in accordance with principles like solidarity, democracy, equality and mutualism. Although a large proportion of those involved with the theme (including researchers, cooperative workers and cooperative support institutions) take the founding premise of the cooperative to be to benefit its own associates, these principles are also aimed at improving their surroundings and the local community, access to work and the egalitarian distribution of the results of the collective work realized within the enterprise. In theory, at least, these are some of the principles that the International Cooperative Alliance ${ }^{5}$ advocates at a global level.

Almost always, however, theory differs from practice. It can be observed that the growth dynamics of cooperatives in Italy - a country with one of the world's most developed cooperative systems - has moved them closer to the characteristics of capitalist companies and away from the original aims. Furthermore, in recent years, many of them have invested in productive internationalization, a business strategy common among the small and mediumsized firms of the industrial districts, through which, however, the cooperatives also generally evolve, set up subsidiaries in other countries and increase the number of employees but not their base of associates. These experiences can help us understand a dynamic that has become widely adopted by 'successful' cooperatives - not just in Italy, but also in other parts of the world.

\section{COOPERATIVISM AND PRODUCTIVE INTERNATIONALIZATION}

The process of globalization that began in the I970s and expanded especially in the following decade involved a vigorous internationalization of companies, which also extended to the cooperatives. Although examples exist of cooperatives that had begun to internationalize already in the I96os, this blossomed in parallel with globalization and took on a fairly significant dimension 
with the economic crisis that irrupted in 2008, affecting in particular Europe and the United States, and whose repercussions are still felt today. It is in this context that the practice of Italian cooperatives of shifting their production to other countries is disseminated. Once perceived as a natural strategy for the growth of large companies, this phenomenon is now also often found among small and large companies and cooperatives. ${ }^{6}$ According to Mariotti and Mutinelli (1997), in the mid-I980s there was already a modest but growing movement of Italian companies that set off on new paths through the internationalization of their production. The number of companies in the area of industrial production with operations abroad was 2.5 times higher than the number of foreign companies based in Italy. According to the census conducted at the start of 1996,622 Italian companies were registered during the period with at least one production facility located abroad.

The first contacts that the Italian cooperatives had with the foreign market can be traced back to the start of the I96os, but it was during the following decade that this process really began to take shape. At the end of the I980s, Gori (I988) had already expressed a concern with the growing decentralization of production among cooperatives from the Emilia-Romagna region and its effect on the characteristics of these enterprises. At that time, however, he was unable to predict that the intense process of decentralization would culminate in the internationalization of a significant proportion of these cooperatives.

Today diverse Italian cooperatives seek not only to consolidate themselves in the market in which they are already inserted, but also to expand into new markets abroad. Indeed, these companies are structured by the strategic importance and commercial advantages brought by their expansion into foreign markets. Along these lines, Serenari (2005) sees the entrance into the internationalization of production as the only alternative for the cooperatives to avoid succumbing to competition, losing what previous generations of associates had achieved in their own territory.

As the export and import activities have developed and presented positive results, new forms of investment have emerged and the process of internationalization has acquired other characteristics. In Serenari's view, the intensification of these activities has developed the growing capacity of companies to take on 'international behaviours,' involving a much greater interaction with potential partners. Hence international partnerships, foreign investments and the creation of cross-border networks comprise the new international economic strategies of small and medium-sized companies and cooperatives based in industrial districts.

The first step for companies to initiate their international activities is exportation of their products. This is the simplest and safest step, known as the market-based or commercial form of internationalization, through which 
produce such as machinery, components and final products are sent to other countries to be sold in other markets. Exportation may be either indirect, when the company does not adopt any specific policy to adapt production to the foreign market, or direct, when some of its structure and planning is specifically aimed towards the overseas sale of these products, generally adapted to the intended market. As well as exports, expansion abroad also includes indirect production - which occurs through licenses granted to foreign producers - and direct production - which involves the implementation of production plants abroad, generally constituted either as joint ventures or as companies formed with 100\% foreign capital.

For Serenari (2005), internationalization involves a series of integrated activities that not only boost commercial performance, but also increase the capacity to be competitive in an international economic environment. Vittori (2013), for his part, defines the process of internationalization as a complete geographic relocation of the company's production chain with the objective of achieving the best conditions in diverse markets through direct overseas investment. The latter is designed to allow these companies to increase both the penetration of their production in specific foreign markets and the efficiency of the production cycle itself. In Vittori's view, the concept of internationalization is not limited to exportation or production abroad, it also refers to the final result, the outcome of a long and complex strategic process implicating the company as a whole.

The enterprises that engage in internationalization are able to penetrate foreign markets using a number of strategies, among which we can cite joint ventures, which allow the companies to participate in the ownership of another company, exerting some degree of influence over its management, and tendered contracts, which allow production to be executed in the country where the products will be sold. There are also diverse other forms of international cooperation, such as assistance and service provision contracts, and international research and development agreements, which play a very strong strategic role.

In light of these options, Serenari (2005) emphasizes that internationalization comprises a highly diversified activity, which spans commerce, the formation of cross-border institutions of economic operators, cross-border collaboration itself, the constitution of alliances and/or subsidiaries, branches and joint ventures abroad, as well as the creation of decentralized production conglomerates. Most of the time, these characteristics combine, transform and adapt to the benefit of each company's interests.

In considering the possibility for productive internationalization, the cooperatives receive considerable support and incentive from local and national governments. As well as the support offered by the public sector, there are also cooperative support companies, specialized in dealing with all stag- 
es of the process, from initial research surveying international markets to the complete implantation of a new factory in foreign territory. These companies that inform, assist, support and coordinate the entire procedure may take the form of associations or cooperatives or comprise private initiatives. During our research, we investigated in more depth three such institutions focused on international cooperation: Innovacoop, Coopermondo and Indaco, which over recent years have been widely sought out by small/medium-sized companies and cooperatives wishing to expand their business.

Innovacoop was founded in 2012 by Legacoop from the Emilia-Romagna region. ${ }^{7}$ With the primary objective of making the cooperatives more competitive in the market, its work focuses on stimulating their development and growth through the promotion of the internationalization and technological, organizational and administrative innovation. Its predominant strategy is to offer its clients rational proposals that prioritize economic results. Coopermondo, meanwhile, is a non-governmental organisation set up in 2007 by Confcooperative, ${ }^{8}$ the Italian Federation of Cooperative Credit Banks and the Italian Federation of Fishing Cooperatives. Its goal is to promote sustainable economic and social development, creating international cooperation opportunities for all the members of the federations that make up Confcooperative and that are interested in internationalizing their business. Indaco, in turn, is a second-level cooperative, ${ }^{9}$ composed of 12 cooperatives. The idea of launching it on the market came from Simone Mattioli, who twice held the post of president of Legacoop for the Marche region, located in the centre of the country. Possessing ample experience in the cooperative world, he saw the opportunity of a market niche that had been little explored as of 2008 . The idea of forming the cooperative emerged between 2006 and 2007, and was inspired by the activities previously developed at Legacoop, through which relations were established with Latin America, especially with Argentina, Brazil and Uruguay. Like the other institutions, its work is geared towards supporting and administrating the development of the commercial and production activities of Italian companies and cooperatives abroad.

It is important to observe that the agencies representing the cooperative interests linked to the country's main trade union confederations - among them, Legacoop, affiliated to CGIL, ${ }^{\text {Io }}$ and Confcooperative, affiliated to CISL $^{\text {II }}$ - possess organisations exclusively dedicated to the economic internationalization of cooperatives. This fact demonstrates that the union institutions are not only sympathetic to the cause, they vigorously stimulate this process. We can note, therefore, that both the trade union confederations and the cooperative federations have contributed to the amplification of this movement, corroborate the premise of establishing economic results as a priority, and stimulate cooperative ventures to diversify their business on the international market as a way to boost their profits. 
Support for economic internationalization, however, especially when it involves the installation of production plants abroad, is not unanimous among the federations and less still among union representatives. Apparently backing is clearer among the federations - even though they continue to promote studies to analyse the consequences of the process - than among trade unionists. Many of the latter condemn the practice, chief among their concerns being the labour conditions and remuneration of workers abroad, as well as the potential deindustrialization of Italian regions as a consequence of the mass migration of factories overseas. Among our interviewees, the union representative from Federazione Italiana Metalmeccanici (FIM) ${ }^{\mathrm{I} 2}$ told us of his discomfort concerning the tendency for labour and remuneration conditions abroad to be generally worse in comparison to those found in Italy. On the other hand, the representative from Federazione Impiegati Operai Metallurgici (Fiom) ${ }^{\mathrm{I} 3}$ expressed his concern over the lack of jobs in the Imola region, largely due to the transfer of resources and jobs to other countries.

The main motives driving companies and cooperatives to transfer their activities abroad are the attractions that other countries can offer, such as, for instance, tax reductions or exemptions, lower labour costs, the absence of worker benefits, less bureaucracy and, in many cases, the absence of unions and other forms of assistance to wage workers. In this way, companies take advantage of labour regulations and laws less favourable to workers in specific countries in order to obtain higher profits - when compared to equivalent production in the country of origin - without necessarily having to bypass or violate legislation. These facilities used by the governments of diverse countries as incentives for foreign companies induce a general lowering of production costs and end up attracting the attention of numerous Italian businesses of all sizes, which over recent years have increasingly opted to cease investing in industrial districts and to explore new kinds of activities abroad instead.

It is worth emphasizing that the internationalization of cooperatives has not occurred only in Italy. In fact, Mondadore (2013) had already observed this same tendency in her doctoral research on the internationalization of production of the Mondragón Cooperative Complex, located in the Basque region of Spain, which is already highly advanced. Mondadore's studies show that the cooperative complex, founded on the social principles of cooperativism, transformed over time into a multinational complex in which just the parent company or a minority of its ventures function as a cooperative. Not even the Complex's companies operating in the rest of Spain are cooperatives: on the contrary, they are all capitalist companies based on wage labour that generate high profits for the cooperatives and their associates located in the Basque region.

The fact that this process is present in the cooperatives of Mondragón, as well as the Italian cooperatives from the Emilia-Romagna region - two of 
the regions of Europe in which cooperativism is stronger and, in the Italian case, also receiving support and institutional stimulus from important trade union federations - leads us to suspect that this trend is already widely disseminated among the cooperatives, presenting itself as a contemporary evolution of cooperativism, which ultimately represents a definitive rupture with its original ideals.

In the case of the cooperatives from the Emilia-Romagna region, although the internationalization of production has become increasingly common, its consequences have yet to be sufficiently analysed in social and economic terms. And these consequences are not trivial when we note that this strategy is directly related to the conscious and voluntary decision of the cooperatives to take advantage of working conditions generally more precarious and poorly paid than those found in Italy. ${ }^{14}$ It is also linked to the effect of deindustrialization in their territory of origin, leading to higher levels of unemployment and the intensification of economic problems. ${ }^{15}$

Faced by these questions, it is important to stress that the phenomenon of productive internationalization generates a major paradox: in a context of economic slowdown, the companies/cooperatives have increasingly decided to enter foreign markets as a strategy for surviving the crisis, growing and/ or increasing their profits. However, this option of searching for workforces internationally also contributes to the growth of unemployment. As a result, Italy remains in a crisis situation, given that the opposite movement - foreign companies moving to Italian soil - has not been observed with anything like the same intensity. Hence this dynamic has two deleterious effects: on one hand, it can undermine Italian autonomy and economic development; on the other - and this is the most serious impact from the viewpoint of cooperativism - it tends to accentuate the exploitation of labour in those countries that open their doors to internationalization.

As the trade unionist from Fiom/CGIL told us, the concern with the employment rate in the Imola region is today very high, given that the tendency is for the cooperatives to invest more abroad, ceasing to create jobs in the town itself. In his opinion, the cooperatives that invest in production in other countries rather than develop their own home region are aiming merely to increase profits and no longer consider the collectivity or even their own family, given that curbing investments in Imola generates the risk that the current economic crisis may deepen in the region, leading to the closure of more companies and, consequently, leaving their compatriots jobless in the near future.

According to Hancock (2007), the business strategies pursued by the industrial cooperatives result from the tension between social values and the desire to remain competitive on the global market. Given the stance taken by these companies over the years and the form through which the internationalization of production has unfolded, it is evident that global competitiveness 
takes priority over social values. In those cases where cooperatives opt to follow market rules, therefore, the principles idealized by the cooperative movement have been replaced by the goal of obtaining ever higher levels of profit.

Lima (2012) recognizes that the cooperatives need to show efficiency as a business, but their difference in relation to capitalist companies resides in the form in which they are managed and in the collective appropriation of their results. Or put otherwise: if the question of the sharing of the results becomes an issue and collective appropriation involves just a few associates, we need to ask to what point the social economy ${ }^{16}$ is a real alternative to the dominant capitalist model.

\section{COOPERATIVE $X$}

Cooperative $\mathrm{X}^{17}$ is an exemplary case of productive internationalization. Founded in the town of Imola in I9I9, during its early years its operations were focused on servicing and repairing industrial machinery belonging to other cooperatives from the Bologna region. Over the decades, though, it developed into diverse niche markets until it became consolidated in the area of producing and installing automatized machines and equipment for branches of the ceramics, plastics, food processing, inspection systems, drinks and packaging industries. Established as a successful model throughout Italy, the cooperative today has a strong international profile, operating in 28 countries (Brazil included) via 77 of its own companies or joint ventures. With the focus on external markets, it guarantees almost $90 \%$ of its turnover comes from the operations abroad using wage labour.

The cooperative runs all the operations of its group through a head office that supervises the diverse areas of operation. A cooperative member is responsible for the business of all the group's companies related to each one of these sectors. Among the companies belonging to the cooperative, a holding company controls the administrative services of all the units, while another company is responsible for managing the shipping and logistics sector of international transportation, but does not work exclusively for the cooperative group and has clients in various parts of the world. As well as controlling all its subsidiaries, the cooperative also invests heavily in the research and development of technologies.

In 2015 the company had 389 associates from a total of four thousand workers, meaning that less than Io\% of its employees were cooperative members. The cooperative's own regulations stipulate that only workers from the parent company can apply to be associates, a ruling - approved in assembly - introduced in order to limit the access of new associates, excluding all workers hired by its companies, among them those located in Italy and the town of Imola itself. ${ }^{\mathrm{I}}$

The big question concerning Cooperative $\mathrm{X}$ is that it would be a success case were it not for the fact that only the parent company is configured as a cooperative, while all the other 76 units are private companies belonging to 
the cooperative itself and explored by it. On the other hand, it would be a typical case of the success of a private or limited company had the parent company not developed under the guise of cooperativism and had not made use of all the cooperativist premises already enunciated earlier.

As we researched the topic more deeply, we discovered that the internationalization of the cooperatives has become extremely common in Italy and is spreading rapidly. It is not, therefore, an isolated case limited to the cooperative in question or to the Mondragón Cooperative Complex, but a tendency that has been gaining impetus over recent years, especially following the 2008 economic crisis, as emphasized by the directors of the cooperative support agencies that we interviewed.

But why exactly does the internationalization of the Italian cooperatives draw so much attention? Firstly, because the dynamics of internationalization, the way in which it is carried out, contradicts the cooperative principles. Secondly, precisely because Italy is one of the countries where the experience of cooperativism has most developed, serving in some ways as a model for other countries and regions, there is a strong likelihood that these trends will spread to the rest of the world. Moreover, when we take into account the fact that the history of the productive internationalization of cooperatives familiar to us in Italy suggests that this strategy is generally practiced in such a way that only the parent company is configured as a cooperative, while the other subsidiaries belonging to it operate as common private companies that, through their profits, subsidize the existence of the cooperative and its few associates, it becomes clear that the cooperativist ideal has been lost during the process. The productive internationalization of cooperatives, and the way in which it has been pursued, is thus a consequence of the process of degeneration of the cooperatives, which end up undermining the principles of cooperativism. Hence, when the cooperatives become internationalized in the way encountered in our research, it is because they had already degenerated at an earlier moment, relinquishing the basic principles of the social economy.

If, however, the cooperatives end up adopting the same strategies used in response to the market by commercial companies, what actually, in the opinion of the cooperative members, differentiates the Italian cooperatives from the other small and medium-sized companies operating in the industrial districts? According to the unanimous opinion of the Cooperative $\mathrm{X}$ associates we interviewed, the difference resides in the mutualism practiced between its members. Setting out from this observation, we can note that the cooperative members generally associate the term cooperativism with the meaning of mutualism, i.e. the mutual aid between the cooperative's associates, downplaying cooperativism's other principles.

The fact that the Italian cooperative movement frequently confuses charitable action ${ }^{19}$ with the solidarity and community spirit advocated by 
cooperativism provides an insight into the motivation that leads the enterprises to undertake some activities to foster the development of the local community to which its head company belongs and, on some occasions, invests in social projects in countries where they operate (duly benefitting too from the local tax deductions and cultivation of a positive corporate image).

Nonetheless, these actions are trivial compared to the profit that these enterprises obtain from tax benefits and the favourable conditions encountered abroad when establishing a company with wage labour at much lower costs than what would be otherwise spent on associated labour. It may even be said that some degree of democracy, mutualism and solidarity exists among the associates in the cooperative, yet these principles exist for the sole purpose of combining forces to generate profits and increase the company's capital. Since if these principles do not serve to increase worker access to the social base of a cooperative, then it can be presumed that they exist in discourse only with the aim of benefitting those who manage to become members.

\section{FINAL CONSIDERATIONS}

The productive internationalization of Italian cooperatives, which has generally benefited from the support and backing of regional and federal governments, unions and cooperative support institutions, first emerged in isolated form in the business decisions of some cooperatives, but has today become increasingly widespread - especially with the economic situation that took hold in Italy following the 2008 crisis - in Europe as a whole, as directors of the cooperative support agencies reported.

In this setting, the internationalization of the ventures proved to be a viable route for escaping the crisis, and the cooperative movement itself perceived that those companies that had already become internationalized were not facing economic difficulties or had overcome them more easily than those with markets concentrated exclusively within the country.

The Italian industrial producer cooperatives, generally situated in the industrial districts, are following the same paths taken by the capitalist businesses in these areas, exporting and producing abroad in order to compete and excel in a field of intense market competition. Generally speaking, the main objectives of the cooperatives and companies investing in productive internationalization are: to further lower the costs of labour (based on low wages and flexible legislation) and raw materials, despite the effect of worsening labour conditions in countries where the subsidiaries are located; to facilitate logistics, commercial representation and technical assistance; and to increase the competitiveness of the parent company on the global market. In following this path, though, they became increasingly guided by the rules imposed by international capital, distancing themselves from the needs of the wage workers employed by their national and foreign enterprises. 
It is also worth emphasizing that the opening of production plants abroad harms the economy of the cooperative's home country: as the Fiom trade unionist warns, the practice of producing in other countries as a means to lower production costs has contributed substantially to a growth in unemployment (or to employment rates stagnating) and Italy remains in a crisis situation, given that the opposite movement, international companies transferring their production to Italy, has proven insufficient to meet the demand for jobs. At the same time, the cooperatives have turned to basing their own development on the high rates of labour exploitation practiced in those countries where their subsidiaries are located, a blatant contradiction of cooperativism's ideals of solidarity.

Given this scenario, we can note that the process of internationalization is one of the principal elements, if not the main element, in the degeneration of cooperatives today. Recognizing, however, that the kind of internationalization taking place in Italy is, as we have already remarked, a conscious choice of the cooperatives, intended to expand their business and boost their turnover through the use of cheaper wage labour, we believe that this choice stems from the fact that the cooperatives are closer to capitalist values than to any original social and solidary principles and that they have, therefore, already degenerated at an earlier moment.

Also closer to the capitalist ideals than to those of cooperativism are the cooperative support institutions (the confederations of cooperatives, for example, and some of the workers' unions), as well as the cooperative members themselves. In fact, the former perceive the cooperatives as commercial companies that need to be inserted in the competition of the international market. The cooperative support agents in particular defend this theory emphatically, since most of the time this comprises the day-to-day work of the institutions dedicated to cooperative development: defending and representing the interests of the cooperatives in the home country or in the international market. And currently the biggest interests of the enterprises with which we had contact in Italy revolve around their expansion and profitability. The cooperative members, for their part, see the cooperative as a normal capitalist company, which first and foremost needs to focus on business and beat the competition. Most of our interviewees stated that the cooperative is a company rather than a cooperative.

It is important to stress that, historically speaking, the cooperatives were born as a movement of workers who, through mutual aid, united to confront the adversities imposed by capitalist competition. The results of our research indicate, however, that the worker has been superseded by the market. When the enterprise is seen primarily as a company, it is clear that the social and solidary principles and self-management are no longer in the foreground but increasingly distant. 
In reflecting on the cooperative movement, it is interesting to observe that there are century-old enterprises that have grown, developed and established themselves as leaders in their branch of work and that still invest in the surrounding community. But when a cooperative retains control of another 76 companies spread across 28 countries with less than Io\% of its workers included in its base of associates, the principles of cooperativism and the social economy seem ever more distant from those ideals cherished by the founders of the movement and proclaimed by the first cooperatives in the nineteenth century when the Rochdale Society of Equitable Pioneers emerged in England. This is not an isolated case, moreover: cooperatives are gradually investing in productive internationalization with the support and backing of governments and the union movement, taking a path that is becoming increasingly incompatible with the values and ideals of the social economy. Undoubtedly, the findings of our research need to be complemented by new investigations in other countries in order for us to be able to reach any conclusions about a broader trend towards productive internationalization with the characteristics described here. However, the fact that this path has already been widely adopted in Italy, as well as the Mondragón Cooperative Complex in Spain, is far from reassuring.

It is worth reiterating that the success of the cooperatives that have internationalized their production is based on the exploitation of labour in each subsidiary around the world. Through wage labour, low pay (very often enabled by favourable exchange rates and the legislation in force in the countries), flexible labour laws and the exclusion of workers from the base of associates, the cooperatives obtain innumerable economic advantages that would be impossible were production concentrated exclusively in their home country. There is no doubt that it amounts to a great success in terms of business, but is a definitive step backwards for the cooperative movement and the social economy as a whole.

Our research leads us to believe that the deep degeneration of the cooperatives in Italy may reflect a more general tendency in contemporary cooperativism. The reality made evident by our investigation suggests that such ventures are being shorn of the characteristics of the social economy and that the cooperative movement, for its part, is not only losing its capacity to maintain the spirit of cooperation but also encouraging the cooperatives to become more competitive and profitable at the expense of what this means for its founding ideals. The question that emerges from the research, then, is the extent to which it is possible to avoid the degeneration of cooperatives prospering in the current phase of globalization through which we are living. How can cooperatives be successful without moving away from their original principles, facing competition in a global market without making indiscriminate use of wage labour based on precarious working conditions and low pay? 
The objective of this article is not to propose solutions to this challenge, but to expose the questions provoked by productive internationalization, a practice that has increasingly been gaining the sympathy of the cooperative movement and the investment of social enterprises. In this context, the concepts of social economy and cooperativism become jumbled and limited to the characterization of experiences that unite associates seeking to create the conditions for expanding the cooperative businesses in order to reap benefits for themselves. Modern cooperatives propose merely to benefit their associates in proportions increasingly restricted from their workers as a whole. There are no plans to increase the social base of the cooperatives. There are no strategies to fight for a fairer and more egalitarian market. While the social economy is widely debated in the academic environment, it is seldom present in the day-to-day life of the workers.

In this sense, the research findings pose a question concerning the capacity of cooperativism to resist the forces promoting the internationalization of capital, which appear as one more serious obstacle to the ideals of cooperation. While, on one hand, the entry of cooperatives into productive internationalization is understood as an alternative for them to avoid succumbing to competition and losing what previous generations of associates have achieved, as made clear, we also need to consider that globalization, such as has been faced by the cooperative movement, makes cooperativism practically unviable.

Cooperation effectively occurs when those at the margin of the system associate in order to survive by producing on the basis of the ideals of mutualism, solidarity, self-management and collective ownership of the means of production. In these cases, cooperation occurs because these marginalized individuals join together as a form of making their inclusion in the system possible. If, however, once included, they are unable to find concrete alternatives to involve more workers in the project, they cease to be solidary. And without doubt, they are not engaged in cooperation.

Received on I7/Io/2016 | Revised on I3/02/2017 | Approved on I0/05/2017 
Marcia de Paula Leite has a PhD in Sociology from the University of São Paulo and is a full professor at the Campinas State University (UNICAMP), where she currently teaches on the Postgraduate Programs in Education and Social Sciences.

Her main research interests are labour markets, restructuring of production, and gendered social relations.

Raquel Duaibs has a PhD in Social Sciences from Campinas State University with a sandwich period at the Università di Bologna (Italy), and is a professor at the São Paulo Faculty of Technology (FATEC). She works in the area of industrial and labour sociology, and her main research interests are solidary economy, social movements in Brazil and Italy, and the internationalization of cooperative companies. 


\section{NOTES}

I The emergence of the Italian cooperatives and the development of the cooperative movement in the country is an important topic for any analysis of their current characteristics. However, the present article does not intend to explore the theme here, maintaining its focus instead on productive internationalization. To learn more about the history of these cooperatives, as well as their relation to parties and unions, fundamental in their process of development, consult Capecchi (1992), Menzani (2007) and Duaibs (2016).

2 The mutual aid associations and cooperatives emerged in the kingdom of Italy even before the process of unification of the Italian states had been completed, observing that the region initially comprised a conglomeration of small States subject to foreign powers. No consensus exists among historians on the real date of the country's unification, but the majority consider the process to have begun in I8I5 with the Vienna Congress and ended in I87I with the annexation of the State of Rome. However, I86I was considered the year of the proclamation of the Kingdom of Italy and thus the official year of unification of the country.

3 This law (no. I577/47) sets out the solidary and democratic principles by which the cooperatives should be inspired, as well as stipulating the requirement to hold indivisible reserves in a fund dedicated to maintaining the cooperative's surplus capital.

4 Law no. 49, issued 27 February 1985, instituted the offer of credit to cooperatives.

5 An institution founded in I895 with the objective of representing, supporting and developing the cooperative movement around the world. The premises governing this independent non-governmental organisation include seven fundamental points: I) Free and voluntary membership; 2) Democratic control by members; 3) Economic participation of the associates; 4) Autonomy and independence of each cooperative; 5) Education, training and information on cooperativism; 6) Cooperation between cooperatives; 7) Concern for local communities. 
6 Cooperatives in Italy are usually small to medium-sized companies. Zamagni (2013) compares them to the typical small Italian multinationals, which are competitive at global level but are not large in size.

7 Founded in I886, the Lega Nazionale delle Società Cooperative Italiane is Italy's oldest cooperative organization. Its main objectives are to represent the cooperatives and to develop projects and services that promote the cooperative culture. Popularly known as Legacoop, the institution represented, in 2014, more than 15,000 cooperatives throughout Italy.

8 Articulated by the Catholic cooperative movement, the Confederazione Cooperativa Italiana, known simply as Confcooperative, was created in I92 I with the aim of bringing together the cooperative federations with a Catholic orientation.

9 The cooperative legislation in Italy provides for the existence of first-level enterprises, formed by individuals, i.e. workers, and second-level enterprises, which are created by legal entities, specifically other cooperatives, forming a kind of consortium.

Io The Confederazione Generale Italiana del Lavoro (CGIL) emerged in 1906 and is the main union confederation in Italy.

I I The Confederazione Italiana Sindacato Lavoratori (CISL) was founded in 1950 with the aim of constituting a Catholic-inspired union confederation.

I2 FIM is the metalworkers' union associated with CISL.

I3 In free translation, the 'metalworkers federation.' Fiom is the metalworkers' union affiliated to CGIL.

I4 A study conducted via a partnership between the Confederazione Italiana Sindacato Lavoratori and the Institute of Contemporary Observation during the period from 2009 to $201 \mathrm{I}$ in the Guangdong province of China, among I6 Italian companies or firms backed by Italian capital (including at least one cooperative) with factories in the Chinese region found that most of the researched companies treated their Italian workers (in the plants in Italy) differently from their Chinese workers (in the Chinese plants) and failed to respect the principles of the inter- 
national labour standards set by the ILO. The research also emphasized that most of these companies offer wages and social benefits below the minimum necessary standard established by Chinese legislation, impose long work shifts, fail to meet health and work safety regulations, and violate the right to freedom of association and collective bargaining. For more details on the study, see the Institute of Contemporary Observation (20II).

I5 The question of deindustrialization and unemployment in the country of origin of the capital invested abroad is far from simple. When the company enters new markets and begins to manufacture products in these new regions as a form of adapting to the market in question, it cannot be said to be generating unemployment or deindustrialization in its country of origin: it has merely acquired new markets. Unemployment and deindustrialization in the country of origin of the capital occur, though, when the company, as a result of lower production costs, begins to produce merchandise abroad that will be consumed in its own country.

I6 Some authors use the expressions 'social economy' (more familiar in European and North American countries) and 'solidary economy' (popularized in Latin America) as equivalents while others distinguish between them. França Filho (2002:13), for example, argues that the social economy includes, as well as cooperatives, some large-scale forms of association, mutualist organisations and foundations, and is characterized by "experiences that are supported by the development of economic activities for the realization of social objectives, also contributing to the affirmation of ideals of citizenship." The solidary economy, on the other hand, is a movement of historical revision and renewal of the social economy, which has a political project for society. Despite the differences between these two concepts, it is important to recognize that most of the authors consider the phenomenon to be an economic activity based around the ideals of solidarity, equality and democracy that works towards the social inclusion and welfare of its members.

I7 Cooperative $\mathrm{X}$ is the name used by ourselves for the cooperative researched by us in the town of Imola. All the information and data from the company are true, only the name has been concealed in order to protect its identity. 
I8 A detailed study of the history of Cooperative $\mathrm{X}$ can be found in Duaibs (2016).

I9 As an example of charitable actions, some cooperatives donate medical equipment to hospitals or subsidize the professional training of young people living in situations of social vulnerability.

\section{BIBLIOGRAPHY}

Baldacchino, Godfrey. (I990). A war of position: ideas on a strategy for worker cooperative development. Economic and Industrial Democracy, II, p. 463-482.

Barberini, Ivano. (2009). Come vola il calabrone: Cooperazione, etica e suiluppo. Milano: Baldini Castoldi Dalai editore.

Capecchi, Vittorio. (1992). Un caso de especializacion flexible: los distritos industriales de Emilia Romagna. In: Pyke, Frank; Becattini, Giacomo \& Sengenberger, Werner (eds.). Los distritos industriales y las pequeñas empresas. I: Distritos industriales y cooperacion interempresarial en Italia. Madri: Ministerio de Trabajo y Seguridad Social.

Cornforth, Chris. (2007). Alguns fatores que afetam o sucesso ou o fracasso de cooperativas de trabalho: uma revisão das pesquisas no Reino Unido. In: Lima, Jacob C. (ed.). Ligações perigosas: trabalho flexível e trabalho associado. São Paulo: Annablume.

Cornforth, Chris. (1995). Patterns of cooperative management: beyond the degeneration thesis. Economic and Industrial Democracy, I6/4, p. 487-523.

Doucouliagos, Chris. (1990). Why capitalist firms outnumber labor-managed firms. Review of Radical Political Economics, $22 / 4$, p. $44-67$.

Duaibs, Raquel. (20I6). Êxito ou revés? O dilema das cooperativas que prosperam. Doctorate Thesis. Programa de PósGraduação em Ciências Sociais/Universidade Estadual de Campinas.

Egan, Daniel. (I990). Toward a Marxist theory of labormanaged firms: breaking the degeneration thesis. Review of Radical Political Economics, 22/4, p. 67-86. 
França Filho, Genauto Carvalho de. (2002). Terceiro setor, economia social, economia solidária e economia popular: traçando fronteiras conceituais. Bahia análise e dados, Salvador, I2/I, p. 9-I9.

Gori, Mauro. (I988). Verso un sistema di imprese cooperative: riflessioni sulla realtà della Emilia-Romagna. In: Carbonaro, Antonio \& Gherardi, Silvia (orgs.). I nuovi scenari della cooperazione in Italia: problemi di efficacia e legittimazione sociale. Milano: Franco Angeli.

Hancock, Matt. (2007). Competere cooperando - Il distretto cooperativo di Imola. Imola: Bacchilega Editore.

Lima, Jacob Carlos. (2012). Cooperativas, trabalho associado, autogestão e economia solidária: a constituição do campo de pesquisa no Brasil. In: Georges, Isabel P. H. \& Leite, Marcia de Paula. (eds.). Novas configurações do trabalho e economia solidária. São Paulo: Annablume, p. 195-226 (vol. I).

Luxemburgo, Rosa de. (I999). Reforma ou revolução? São Paulo: Expressão Popular.

Mariotti, Sergio \& Mutinelli, Marco. (I997). Le transformazioni strutturali dell'internazionalizzazione produtiva delle imprese italiane. Quaderni di Ricerca, n. 4, ICE Ufficio Studi Economici.

Menzani, Tito. (2007). La cooperazione in Emilia-Romagna: dalla resistenza alla suolta degli anni settanta. Bologna: Il Mulino.

Mondadore, Ana Paula Carletto. (2013). Mondragón é aqui? Cooperativismo e internacionalização. Doctorate Thesis. Programa de Pós-Gradução em Ciências Sociais/Universidade Estadual de Campinas.

Potter, Beatrice. (I89I). The Cooperative Movement in Great Britain. London: Swan Sonnenschein.

Serenari, Sandro. (2005). Strumenti e processi di internazionalizzazione delle piccole e medie imprese cooperative. Bologna: Edizioni Pendragon.

The Institute of Contemporary Observation. (20I I). Indagine sulle condizioni di lavoro nelle imprese metalmeccaniche italiane nel Guangdong (Cina). Pesquisa realizada em parceria com a Iscos e com a Fim-Cisl nazionale. 
Vittori, Rudi. (2013). Export, delocalizzazione, internazionalizzazione. Un'opportunità delle aziende italiane per superare la crisi. Milano: FrancoAngeli.

Webb, Sidney \& Webb, Beatrice Potter. (I9I4). Co-operative production and profit sharing. New Statesman, II/45, Suplemento.

Zamagni, Vera. (2013). Un mondo di varianti: settori e modelli. In: Battilani, Patrizia \& Schröter, Harm G. (orgs.). Un'impresa speciale - Il movimento cooperativo dal secondo doppoguerra a oggi. Bologna: Il Mulino. 
Palavras-chave Internacionalização produtiva das cooperativas; processo de degenerescência das cooperativas; cooperativismo italiano; sindicatos; internacionalização das cooperativas.

Keywords

Productive internationalization of cooperatives; process of degeneration of cooperatives; Italian cooperativism; trade unions; cooperative internationalization.

\section{COOPERATIVAS E INTERNACIONALIZAÇÃO DA ECONOMIA: UM NOVO DESAFIO}

\section{Resumo}

$\mathrm{O}$ artigo discute as recentes tendências do cooperativismo, que vem adotando medidas para expandir sua produção em mercados estrangeiros mediante a internacionalização produtiva, processo eficiente quanto à ampliação de vantagens econômicas, mas alicerçado na utilização massiva do trabalho assalariado e na exclusão deliberada dos trabalhadores da base social dos empreendimentos. Evidencia, a partir da experiência italiana, o processo pelo qual as cooperativas vão se afastando de seus princípios originais e transformando-se em empresas nos moldes da empresa capitalista tradicional, com a única diferença de divisão dos lucros entre pequena parte de seus trabalhadores, que são seus associados. Analisa também a posição sindical sobre a proposta de internacionalização das cooperativas. Com base em informações sobre o mesmo processo no Complexo Cooperativo de Mondragón, identifica-o como uma tendência mais geral do cooperativismo atual, ápice de profundo processo de degeneração das cooperativas.

\section{COOPERATIVES AND PRODUCTIVE INTERNATIONALIZATION: A NEW CHALLENGE}

Abstract

This article discusses recent trends in cooperativism, which has expanded its production in foreign markets through productive internationalization, an effective process in terms of increasing economic benefits, but based on massive use of wage labour, often in precarious conditions. Setting out from the Italian experience, it highlights the process by which cooperatives are moving away from the movement's original principles to develop into companies operating according to the ideals of a traditional capitalist company. The only difference from the latter is that profits are divided among a small number of workers who are also members, as already observed in the Mondragón Cooperative Complex in Spain. The article further analyses the trade union's position in this process, concluding that the internationalization of cooperatives represents a more general trend, the culmination of a deep process of cooperative degeneration. 